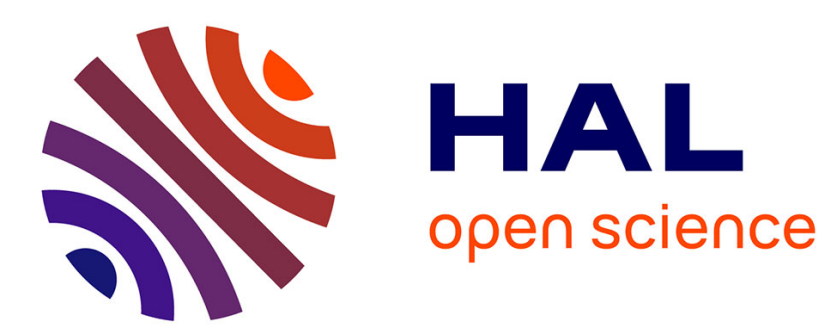

\title{
From Smooth NPMization to Structural Changes in France: Accelerated Reforms, Mixed Perceptions \\ Philippe Bezes, Gilles Jeannot
}

\section{To cite this version:}

Philippe Bezes, Gilles Jeannot. From Smooth NPMization to Structural Changes in France: Accelerated Reforms, Mixed Perceptions. Hammerschmid Gerhard, Van de Walle Steve, Andrews Rhys, Bezes Philippe, Public administration reforms in Europe, the view from the top, Edward Elgar, edward Elgar, pp.56-62, 2016. hal-01340206

\section{HAL Id: hal-01340206 https: / hal-enpc.archives-ouvertes.fr/hal-01340206}

Submitted on 30 Jun 2016

HAL is a multi-disciplinary open access archive for the deposit and dissemination of scientific research documents, whether they are published or not. The documents may come from teaching and research institutions in France or abroad, or from public or private research centers.
L'archive ouverte pluridisciplinaire HAL, est destinée au dépôt et à la diffusion de documents scientifiques de niveau recherche, publiés ou non, émanant des établissements d'enseignement et de recherche français ou étrangers, des laboratoires publics ou privés. 


\title{
From Smooth NPMization to Structural Changes in France: Accelerated Reforms, Mixed Perceptions
}

\author{
Philippe Bezes, Gilles Jeannot
}

\section{This is a preprint version of thepublished paper:}

Bezes Philippe, Jeannot Gilles (2016), "From Smooth NPMization to Structural Changes in France: Accelerated Reforms, Mixed Perceptions" in :Hammerschmid Gerhard, Van de Walle Steve, Andrews Rhys, Bezes Philippe, Public administration reforms in Europe, the view from the top, Edward Elgar, p. 52-61.)

The French public administration has often been considered as one of the most «frozen » public administrations, ranked in between other continental European (Germany) or Southern European states (Spain or Italy). In some recent studies, France was still portrayed as a laggard in terms of administrative reforms (Pollitt and Bouckaert, 2011), requalified as a possible illustration of a 'neo-weberian state' or as a main resistant to the influence of New Public Management ideas (Rouban, 2008), echoeing the historical success of French sociologist Michel Crozier's theory viewing France as a "stalled society" with a "stalled state" (Crozier, 1964; 1970). However, lessons drawn from neo-institutionalist theories (insisting in the national specificity of reform trajectories due to institutional constraints and structuring historical patterns) invite us to more diverse kind of lenses to describe changes and suggest how framing the analysis in terms of inertia can be rather misleading. Indeed, the policies of administrative reforms have developed intensively in the French context as elsewhere, with specificities (Bezes, 2009; Bezes, Parrado, 2013), that may be related to the kind and modes of changes occurring in a 'Napoleonic' state (Ongaro, 2009) or as a Continental State (see Pollitt, Bouckaert, 2011). The importance of gradual modes of changes or, at the opposite, upon long-term perspective in the context of resilient institutions have been emphasised for the French case (Bezes, 2009). Another argument is that New Public Management ideas did develop and diffuse in the French context but with specific institutional constraints (Rouban, 2008; Bezes, 2012). At last, authors have also emphasized the specificities of ministries, some of them (Public Work, Health, Education) developing 
their own dynamic of administrative changes and their own accommodation of managerial tools (Jeannot, Guillemot, 2010; Guillemot, Jeannot, 2013). With these perspectives in mind, this chapter offers interesting insights to emphasize how French top public officials perceive administrative reform policies in France in terms of trends, tools and scope.

\section{The multiple nexus of the French political-administrative institutions}

In order to provide a broad view of the French administrative institutions, four dimensions can be emphasized. The two first are related the degree of pervasivenessof the administrative system. The French state has been recognized as the archetype of a 'unitary and centralized state' - a 'Napoleonic state' - with strong national integration through a single territorial administrative structure (Crozier, Thoenig, 1975; Grémion, 1976). And indeed, national ministerial administrations have subnational units representing subdivisions of the national ministries both at the regional and at the départemental levels. However, second, these regional and départementaldirectorates are also 'supervised' by a 'prefect' who is an agent of the whole government. These lines have designed a territorially based and vertically integrated administrative system, both from the ministerial point of view and from the more political one with the political control defended by prefects. The third component is the existence of a complex legal entrenchment, ranging from a strong legal body of provisions ruling bureaucratic life as well as a statute that organizes the professional life of all civil servants (statut general des fonctionnaires) (Dreyfus, 2000). The French administration hasthus established a large and separate body of administrative law, consisting of a coherent legal doctrine that covered bureaucratic activities. The existence of this 'rigid [legal] backbone' (Knill, 1999, p. 115) explains why any 'new' types of ideas - such as the 'new public management' movement' - have been filtered. The existence of specific training schools designed to train upper-level civil servants (at the top of them, the Ecolenationaled'administration, Eymeri, 2001) is another institutional related feature that even accentuated this trend (Bezes, Jeannot, 2011). The fourth component concerns the political-administrative nexus and points to the relationship between politicians and bureaucrats 'at the top'. On the political side, the French Fifth Republic is often referred to as a semi-presidential regime. The hybrid nature of its politico-administrative system lies in the fact that, although its Constitution of the $4^{\text {th }}$ of October 1958 has established a parliamentary system, both the institutional practice and the constitutional reforms have increasingly 
strengthened the predominance of the President compared with the Prime Minister. The President was initially elected for seven years - while the members of the National Assembly's term lasts five years - but the constitutional reform in 2000 has made the president and the deputies' term match; both now last five years, (theoretically) reducing the probability of 'cohabitation' between a President originating from a different party than his or her Prime Minister. On the administrative side, by reinforcing the presidential and governmental executive against the Parliament, the Fifth Republic has given great strength to top civil servants and has designed fairly politicised minister/mandarin relations. On the one hand, the French administration relies on a vast majority of state civil servants who are recruited through competitive exams, trained in schools and promoted through rationalized mechanisms. The global image that results from these mechanisms is well known: a unified merit and career based civil service system, traditionally associated with the idea of a strong state tradition (État is always capitalised) and the idea of a disinterested civil servant serving the general interest and guarding the public good while also promoting the principles of impartiality, equality, adaptability and continuity. On the other hand, forms of politicization at the top have always persisted and have even been continuously and growingly used as structuring means for steering, producing loyalty and controlling administration at higher level through ministerial cabinets and discretionary appointments (political loyalty is there in balance with expertise and competences) (for an overview, Bezes and Le Lidec 2007).

\section{The trajectory of public administrative reforms in France}

While administrative reforms did not play in France, in the eighties and nineties, the dominant role they had in Anglo-American and Antipodean countries and did not initially claim the same disruptive intentions at changing the very nature of the administrative system, administrative reform episodes in France have been numerous with a steadily growing influence of NPM devices from the nineties and more drastic reforms since the early 2000 (Bezes, 2009). In the early 1980s, France first dealt with decentralisation policies rather than going on focusing on efficiency or managerial tools and the territorial decentralisation was first a response to concerns about the distribution of political power, not about administrative inefficiencies. Competences were transferred to local authorities in several domains (social action, housing, education, culture, transports, sea affairs) but without clearly distinguishing between state and sub-national governments. Although France has been historically 
considered as a centralized state, local representatives and authorities always played a major role at the central level within Republican regimes in France and obtained benefits (Le Lidec, 2001). In this context, decentralisation has always been 'the' major early 'reactive' reform that induced reinforcing effects and changed the 'Napoleonic' state (Le Lidec, 2007, Bezes, Parrado, 2013), for instance with a new decentralization Act in 2003-2004.

In the eighties, smooth administrative reforms valued service quality, user concerns, some managerial techniques (evaluation, contracts) and a continuing set of distinctive public service orientations with strong participation of public servants and control through mutuality. By the mid-1990s ideas, policy instruments, goals and the scope of reform were largely redesigned by the mid-1990s, to such an extent that the New Public Management 'tool-kit' gradually became the dominant inspiration in administrative reform policies (Bezes, 2005; 2009; 2012). At the same time, however, NPM ideas became more influent and growingly adopted by top bureaucrats from the French Grands corps through repeated state reform committees and reports (ibid.)

As a result of these ongoing processes unleashed in the 1990s, many comprehensive and drastic changes have occurred since the early 2000s. The major change for the French administrative system - specifically in terms of adoption of NPM methods and tools - has come from the 2001 reform of the French budgetary procedure. The reform was voted through the Institutional Act on Budget Legislation (Loiorganique relative aux lois de finances, called "LOLF"), adopted on August $1^{\text {st }} 2001$ and implemented since January 2006. The 2001 Budget Act systematised the use of NPM instruments (programme-oriented budgets, a new performance management system, a 'real cost' approach to policy, aggregated headings, constraining capping tools for staff expenditure and a new accountability framework for Parliament) (Bezes, 2010; Corbett, 2010). During the 1990s and early 2000s, the process of agencification was not absent in the French context but it was unsystematic and limited compared to other European countries (United Kingdom, the Netherlands) (Bezes, Fimreite, Le Lidec, Laegreid, 2013). The creation of new autonomous public bodies dominantly took the legal form of the établissements publics, used since decades for many already existing autonomous public bodies (Conseild'Etat, 2012). New agencies were numerous in Agriculture, Health and Risk, Social Affairs, Culture and Research, within this legal form of établissements publics.

After the election of President Sarkozy, a General Public Policy Review was launched in July 2007 with explicit reference to the Canadian Program Review initiated by the Liberal Chretien Government in 1995-1996 or the 'spending reviews' done in UK since 2002 (Bezes, 
2010). The French RévisionGénérale des PolitiquesPubliques(RGPP) claims to engage in "rethinking the state" with direct ties to the fiscal imperatives of dealing with the debt and the deficit. From 2007 to 2012, this process of reform generated two dynamics of transformation of the state organizational form with sharp and specific impacts on the territorial state, the many ministerial field units and the prefects (Bezes, Le Lidec, 2010; Poupeau, 2011). First, boundaries between ministries were redrawn and the number of full ministers was significantly reduced leading to the creation of meta-ministries. Second, the territorial state administration was reorganized at the regional and the départemental levels through many mergers affecting nearly all state local units. Within the same General Review of Public policies, several austerity measures also affected the civil service (freeze on the point value of civil service pay from 2010, non replacement of one in two retiring civil servants).

\section{The specificities of the major trendsofreforms: high on downsizing and mergers; low on transparency and citizen participation}

As regards the big reform trends identified by the respondents in France (question 17), it is no surprise to find that the main responses describe the reforms of the last five years conducted under the general public policy review (RGPP) and reflect the sedimentary layers of previous reforms, which are perceived as less dominant and at work because a bit older. $80 \%$ of respondents (scale 1-3) ${ }^{1}$ identify the impact of the "Public Sector Downsizing" measures: they correspond to the sustained policy of cutting public sector employment over this period by the non-replacement of one in two retiring civil servants. This trend is specifically strong in the French context and is much above the COCOPS average (see table 1). This austerity trend is confirmed by the $69 \%$ that are opposed to the idea that there is and extending state provision into new areas, neatly beneath COCOPS average. The second item particularly identified was the policy of organizational merger (51\%), again above the COCOPS average, which actually corresponds to the multiple reorganizations associated with the RGPP: mergers of central government administrations, of ministerial divisions at the regional level and of interministerial divisions at the départemental level. Associated with this is the presence of reforms focusing on collaboration and cooperation between different players (51\%). In fact, mergers of central administrations as well as, systematically, of ministerial units at regional level was decided in order to increase

\footnotetext{
${ }^{1}$ In this chapter, we have chosen to provide percentages (on scale 1-3) from the French sample in order to emphasize the way surveyed people have responded to the questionnaire. In the three figures we insert, we use means as the simplest way to compare French responses to their European counterparts.
} 
cooperation between them. The reforms relating to performance targets and linked with the LOLF, first implemented in 2006 before the Sarkozy era, take a back seat. However, the respondents underline the importance of focusing on outcomes and results as broadly high at $50 \%$. These measures, clearly dominated by the downsizing theme, which has the biggest psychological impact and affects organizations in their operation, are nevertheless not equated with market type reforms: this is evidenced by the mere $9 \%$ of responses on the question of "privatization" and, to a lesser degree, for "flexible employment", external partnership and "contracting out", respectively $22 \%, 30 \%$ and $33 \%$. To a significant extent, $56 \%$ of the senior executives also identify the progress of digital government (or e-government) as broadly important, but also the creation of autonomous agencies (in France, taking the form of a growth in public establishments), which $38 \%$ of them see as broadly important.

Figure 1: French Top Executives' assessments of reform trends in comparative perspective

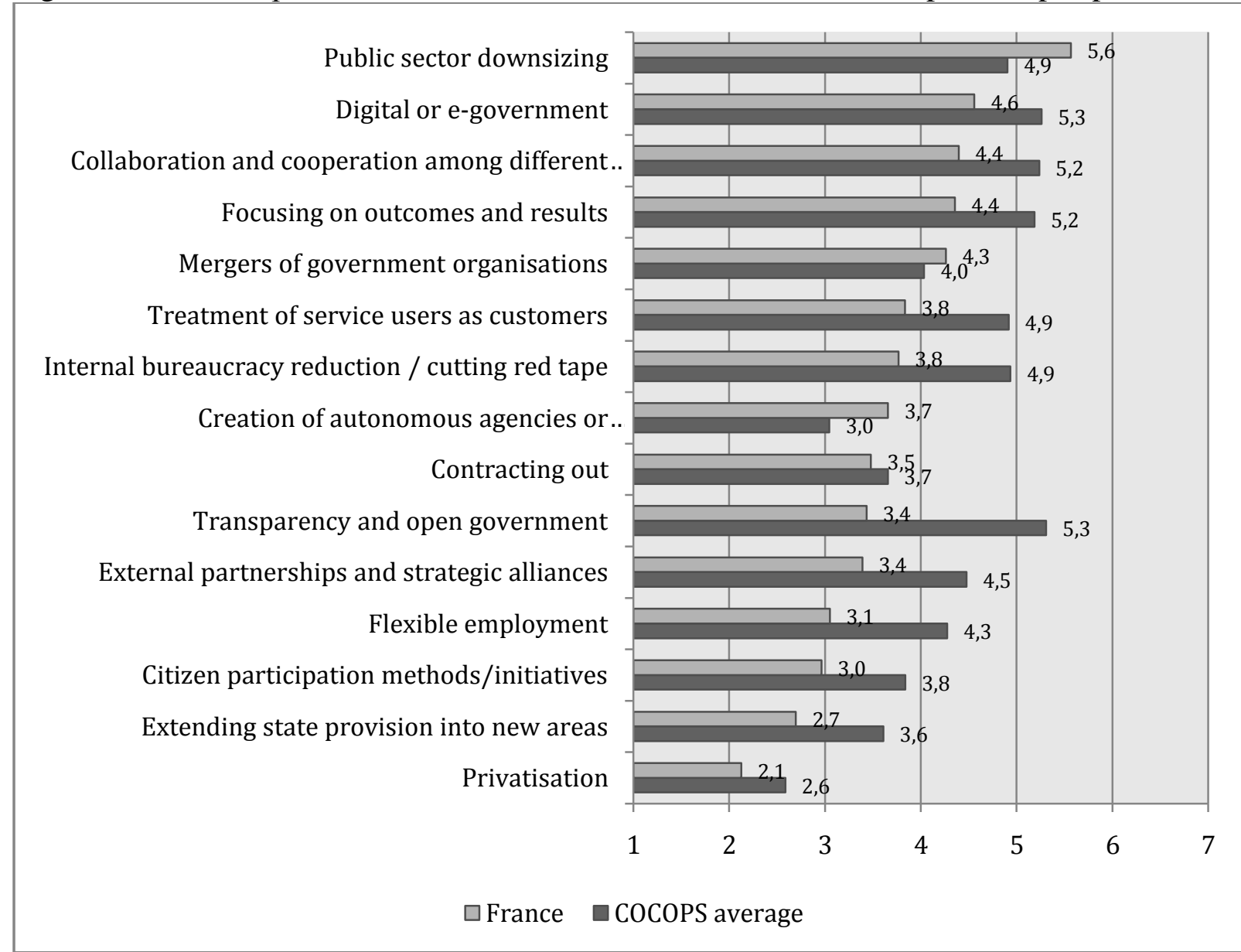

Generally speaking, the respondents' perceptions and responses help defining a fairly accurate map of actual reforms in France. To situate France internationally, we can see a link between austerity policy (downsizing) and drastic reorganizations through merger bringing both cooperation issues to the heart of the reform process and the aim at generatingeconomies 
of scale. Reforms of a different kind (transparency, citizen participation) attract little attention, at least because they were not much represented in the Sarkozy era reforms. NPM priorities (the focus on results; agency creation) reflect more ancient or more 'low profile'but solid trends of change. While France belongs to the lowest ranked countries on many trends, it is quite striking that downsizing, mergers and agencification are the sole three trends above the COCOPS European average. Structural reforms and austerity measures seem to prevail at the expense of changes that would rely on either market tools or citizen-oriented measures.

Figure2 below looks now at senior executives' overall perceptions of the implementation of administrative reforms. These assessments clearly relate to the recent reforms introduced under the general public policy review.

Figure 2: French Top Executives' assessments of the implementation of reforms in comparative perspective

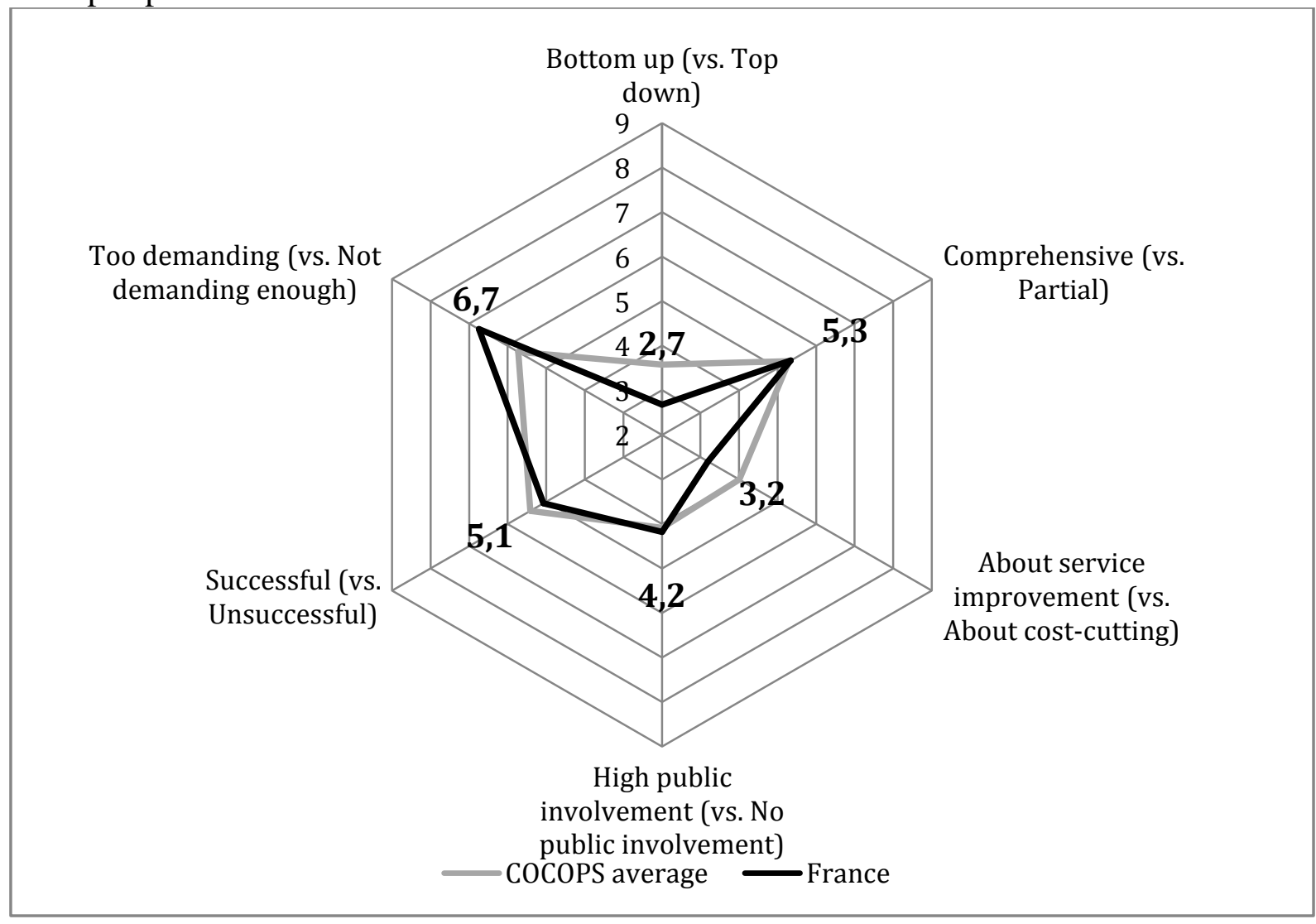

All in all, the assessments are uniform and broadly consider (scale 1-3) that the reforms are top-down (79\%), substantive (i.e. drastic and very visible, 39\%), little concerned with negotiation (contested by the unions $72 \%$ ) and very much about cost-cutting and savings (68\% versus $9.5 \%$ who consider them to be driven by quality improvement) and "driven by the crisis" (48\% compared with planned for only $14 \%$ ). The pushiness of the recent reforms is 
emphasised in several responses. $34 \%$ of respondents see them as largely driven by politics (compared with $22 \%$ as driven by the senior executives), which reflects the 'politics of conviction manifested by the 'hyper President' Sarkozy, to describe the way Nicolas Sarkozy has constructed his political authority. Besides, the audits and reform plans within the General Review of Public Policy were initially elaborated by small closed circles of top bureaucrats and consultants without cooperation and negotiation with ministries. Possibly related to the views that recent reforms were set up by the top, far away from the ordinary problems of top executives, the assessments of reform effects are cagey, with $22 \%$ seeing them as unsuccessful, whereas $13 \%$ consider them a success. The perception of the reforms as excessively intensive can be appreciated by the fact that $38 \%$ of respondents thought that there were too demanding, whereas only $9 \%$ thought there were not enough. The coexistence of mergers and downsizing may explain this perception: both are strongly demanding trends generating many side effects in public organisations(disorganised public policies, material issues related to mergers) and over public agents (trouble in identities, reshuffle of positions in the organisation, etc.).

\section{Reforms by Instruments: the diffusion of managerial tools in the French context}

Beyond the perception of the major reform trends, the assessment by senior civil servants of the instruments actually used in their parent organization is a good indicator of the changes underway in public administration and its intensity. In comparative perspective, the French top executives have declared that, in total, France has one of the weakest 'equipment rate' in managerial tools in Europe, with the exception of Spain, and together with two other Continental countries, Germany or Austria. Like in all other countries, three instruments are perceived as very significant in the French context: staff performance interviews (88 \%), management by objectives and results (69\%) and business planning (59\%).The stamp of performance management methods based on the previous reforms (LOLF) is here rather strong. In complement, the high score of staff appraisal, even above the COCOPS average, reflects the measures taken during the Sarkozy presidency, which extended the individual performance interview (about career development, performance, etc.) to the detriment of bureaucratic scoring mechanisms.

While performance pay is not at the top of list of instruments used in France, its adoption is relatively advanced compared to other countries. Indeed, top bureaucrats have 
been the leading beneficiaries of this system in France since 2006, not only to incentivize their conducts but also as indirect way to increase their salaries.

Figure 3: French Top Executives' assessments of the perceived implementation of managerial tools in comparative perspective

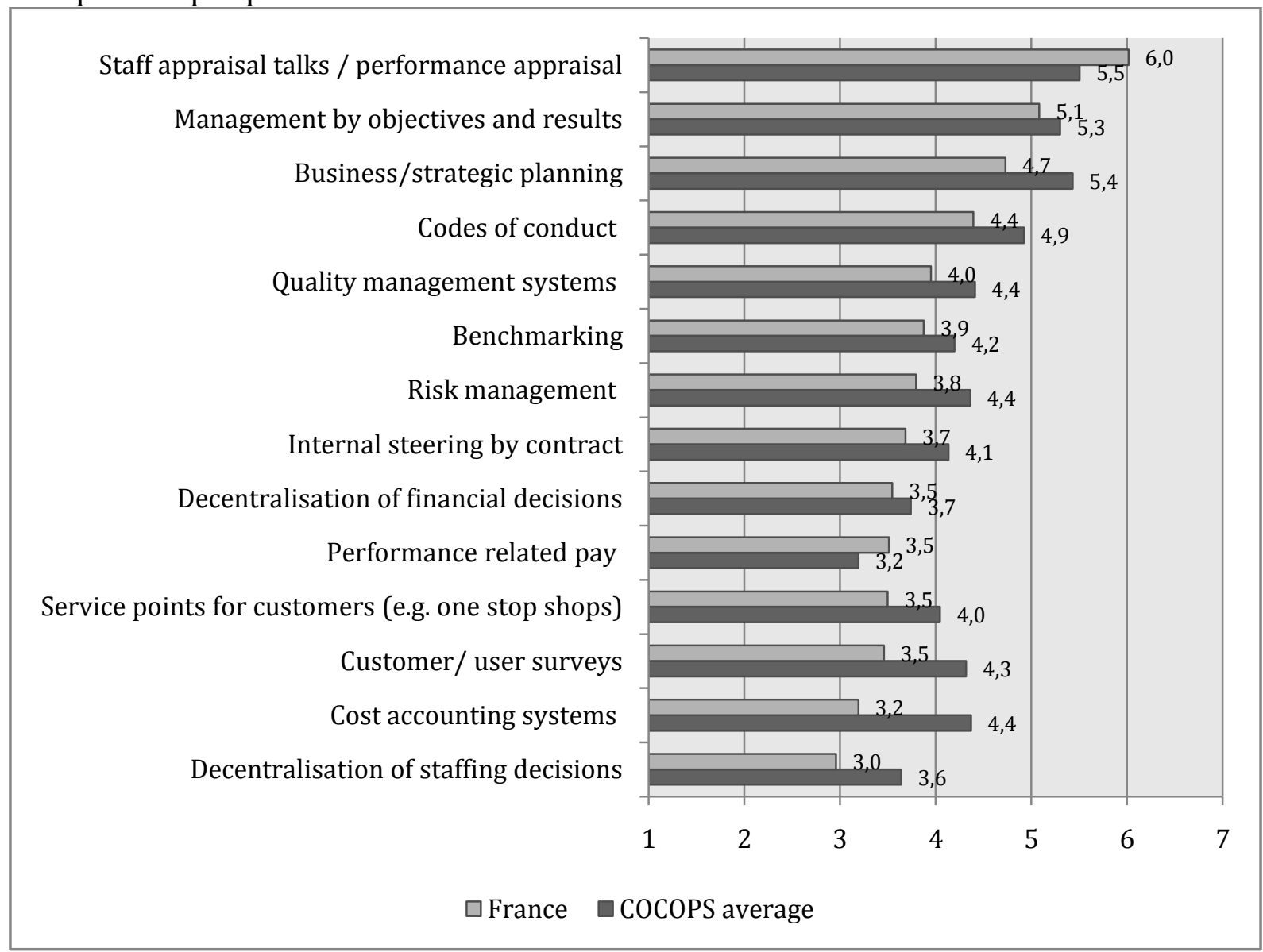

Quite significantlyin order to characterizing France (see figure 3), three types of instruments coming out of the New Public Management toolkit are largely seen as not being widespread. The first type is cost accounting systems (58\% see them as broadly absent) that do not seem to come as a complement of performance management by objective and indicators. This finding can be associated to another result emphasizing that only a small number of respondents perceive a clear reward $(8 \%)$ or penalty $(6 \%)$ for achieving objectives: while systems of management by results are indeed in place, their impact is limited and they are not much used as instruments of discipline or related to incentives.A second remarkable difference between the French findings and those of other countries is the weak focus on customer service, illustrated by the low score of tools like 'service points for customers' or 'customer user surveys'. A third specificity suggests that France nicely illustrates the type of unitary centralized stateswhere both the resilience ofinstitutional protection (a statute for civil servants)and the weight of centralised mechanisms strongly limitthe decentralization of 
financial decisions and of staffing decisions (respectively $50 \%$ and $66 \%$ not present). In the French context, the 'let the managers manage' slogan doesn't seem to be really implemented. The results also confirm well-known components of the traditional nature of personnel management rules in the French civil service and the highly controlled rules of recruitment and promotion. Accordingly, responses to questions on the quality of coordination clearly show the force of vertical, compartmentalized operation and fragmentation between ministries. Indeed, $87 \%$ of respondents to question 13 state that in the event of conflict between organizations, the usual preferred solution is to refer the problem up the hierarchy. This approach is by far the most dominant. Next comesthe decision to shift the problem to the political level $(61 \%)$ and the establishment of an ad hoc project group (48\% of respondents).

\section{Many mixed perceptions ofthe effects of administrative reforms}

Compared to other top executives in other European countries, French top public officials are more critical about changes in the public sector. The general assessment of the global performance of the French public administration for the last five years (question 16) is marked bya significant negative bias. If we take a scale of 3 , the negative views are predominant: $29 \%$ broadly worse vs. $16 \%$ broadly better. Generally speaking, all the judgments about performance vary according to the respondent's level of responsibility, becoming more critical the further down the hierarchy we go. On specific items, the most favourable assessments, indicating an improvement, are few and relate to costs (54\% on scale 3 ) and innovation (49\%). This suggests a fairly restricted view of the improvements, since the first item reflects the numerous initiatives in the RGPP designed to cut spending, and the second refers to technological changes (e-government, Internet). By contrast, a large number of areas are perceived as having clearly declined. Certain perceptions of decline relate to the "external" effects arising from administrative action: the most remarkable (and the most worrying?) results in this sphere are that the senior executives surveyed consider that social cohesion has deteriorated (59\% vs. 10\%) along with citizen trust in government (59\% vs. $10 \%$ ). To a lesser degree, $45 \%$ of the respondents (vs. 23\%) consider that citizen participation is also falling. The other clear perceptions of deterioration relate to the "internal" negative perception of the public sector and of the morale of its staff: $56 \%$ of respondents (vs. $19 \%$ ) thus believe that staff motivation has deteriorated and $52 \%$ (vs. 21\%) that the attractiveness of the public sector (i.e. of the government) as an employer has diminished. 
These results indicate a certain malaise amongst French senior executives and the sense of a government that is enfeebled and out of touch. It seems a long time since administrative reform measures place the emphasis on participation by civil servants and users (Rocard reform of 1989, Jeannot, 2003; Bezes, 2009) and the globally severe perception of reforms suggests a risk of reform fatigue from top executives coupled with the idea that reforms do not benefit to citizens as well as with negative side-effects on the place and role of the civil service in the French society.

Another major issue of concern is the variations in reform' perceptions across the organizational layers of the French administration. One could talk about a French public administration with three distinct layers, differently affected by reforms. If we consider the total French sample of respondents (1193 responses), not used in this book, which includes the chief executives of the French ministerial regional units in addition to top bureaucrats from ministerial central administrations and agencies, we observe a major difference between agency directors and directors of regional ministerial units, representing central government ministries at regional and départemental levels. Agency directors declare to be the most exposed to market mechanisms (benchmarking, contracting out), cost accounting systems and user surveys while also seeingthemselves as highly autonomous compared to the two others and having the most positive perception of reform effects. By contrast, directors of regional and départementalministerial units see themselves as having little autonomy except in reorganizations and mergers' implementation, have a more negative perceptions of reform impacts (most of all at the départemental level) and have been specifically affected by mergers, downsizing and one stop shops. Besides, while agencies' chief executives perceive their organization as extending state provisions, heads of regional and départemental ministerial units perceive the opposite. These findings confirm that agencies, in France, have been at the leading edge of implementing PM tools compared to other government areas and also constitute the layer through which new public policies have been launched. By contrast, the regional ministerial state has been growingly subordinated through administrative reforms that reduce its autonomy because central administrations has made a strategic use of reforms to strengthen their steering over them.

\section{Conclusion}

After years of misleading discourses about France viewed as a laggard on the one hand and, on the other, more radical recent administrative reforms launched by President Sarkozy 
with strong rhetoric of conviction and voluntarism, one could wonder what the COCOPS survey would emphasize. From the French findings, we conclude that administrative change did occur and was perceived by top executives as a complete opposite picture of what were administrative reform policies in the 1980s and early 1990s. Reforms have been perceived as structural, top-down, comprehensive and without participation of public agents or trade unions. As for trends, reforms have emphasised mergers, downsizing and digital tools but performance management has also been developed in the French case. From this, have resulted perceived internal tensions within the French administration (demotivation, contradictory assessments of the impacts of reforms and of the performance of the French administration, strong differences between layers of government such as the opposition between agencies and territorial ministerial units, etc.). However, in a comparative perspective, these significant transformations can be nuanced when confronted to the COCOPS observations that that the French administration is far from having beenNPMized and belongs to the second group of European countries, together with other Continental (Germany) and Southern countries (Italy) where reforms have not been as intense and systematic as they were in Nordic, British or Dutch areas.

\section{References}

Bezes, P. (2009). Réinventer l'Etat. Les réformes de l'administration française (1962-2008), Paris, PUF (coll. Le Lien Social).

Bezes, P. (2010), «Morphologie de la Révision générale des politiques publiques. Une mise en perspective historique et comparative », Revue française d'administration publique, 4, 2010, p. 769-796.

Bezes, P. (2012), «État, experts et savoirs néo-managériaux. Les producteurs et diffuseurs du New Public Management en France depuis les années $1970 »$, Actes de la recherche en sciences sociales, 2012/3 $\mathrm{n}^{\circ}$ 193, p. 16-37.

Bezes, P., Fimreite, A.-L., Le Lidec, P., Lægreid, P. (2013), "Understanding Organizational Reforms in the Modern State: Specialization and Integration in France", Governance, vol. 26, 1, pp. 147-175.

Bezes , P., Jeannot G. (2011), "The Development and Current Features of the French Civil Service System" in Frits M. van der Meer, ed., Civil Service Systems in Western Europe, Edward Elgar, 2011, p. 185-216

Bezes, P., Le Lidec, P. (2007), 'French Top CivilServantsWithinChangingConfigurations. FromMonopolisationtoChallenged Places andRoles ?' in Edward C. Page and Vincent Wright (eds.), Fromtheactivetotheenablingstate. The changingrolesof top officials in European Nations, London: Palgrave/MacMillan, pp. 121-163.

Bezes, P., Le Lidec. P. (2010). «L'hybridation du modèle territorial français. La réorganisation de l'administration territoriale de l'Etat et la Révision générale des politiques publiques », Revue française d'administration publique.4 : 881-904. 
Bezes, P., Parrado, S. (2013), "Trajectories of Administrative Reform: Institutions, Timing and Choices in France and Spain", West European Politics, Vol. 36, 1, January, pp. 26-53.

Conseil d'Etat (2012), Les agences : unenouvellegestionpublique? Etude annuelle 2012, Paris, La Documentationfrançaise.

Corbett, A. (2010), "Public managementpolicymaking in France: legislatingtheOrganic Law on Laws ofFinance (LOLF), 1998-2001 “, Governance, 23 (2). pp. 225-249

Crozier, M. (1964).The Bureaucratic Phenomenon, University Press of Chicago.

Crozier, M. (1970), La société bloquée, Paris, Le Seuil.

Crozier, M. Thoenig, J.-C. (1975). 'La régulation des systèmes organisés complexes. Le cas du système de décision politico-administratif local en France', Revue Française de Sociologie, 1, 3-32

Dreyfus, F.(2000), L'invention de la bureaucratie. Servir l'Etat en France, en GrandeBretagne et aux Etats-Unis (XVIIIème siècle-XXème siècle), Paris, La Découverte.

Eymeri, J-M. (2001) La fabrique des énarques, Paris, Economica

Grémion, P. (1976). Le pouvoir périphérique. Bureaucrates et notables dans le système politico-administratiffrançais, Paris: Le Seuil.

Guillemot, D., Jeannot, G., (2013). 'Modernisation et bureaucratie. L'administration d'Etat à l'aune du privé », Revue française de sociologie, Janvier-Mar, pp. 83-110

Jeannot, G. (2003), "The "service project" experience in the French civil service", International journal of public sector management, $16-6$ p. 459-467

Jeannot, G., Guillemot D. (2010). "Réformer par les outils ou par les hommes ? Un bilan quantitatif de la modernisation de la gestion de l'Etat ». Politiques et Management public, 4: 73-102.

Knill, C. (1999) 'Explaining Cross-National Variance in Administrative Reform: Autonomous versus Instrumental Bureaucracies', Journal of Public Policy, 19, p. 113-139.

Le Lidec, P. (2007). "Le jeu du compromis. L'Etat et les collectivités territoriales dans la décentralisation en France", Revue Française d'Administration Publique, n 121-122, p. 111130.

Ongaro, E. (2009). Public Management Reform and Modernization: Trajectories of Administrative Change in Italy, France, Greece, Portugal and Spain. Cheltenham: Edward Elgar.

Pollitt, C., Bouckaert, G. (2011). Public Management Reform: A Comparative Analysis - New Public Management, Governance, and the Neo-Weberian State. Oxford UniversityPress

Poupeau, F.-M. (2011), «(Con)fusiondansl'Etatdépartemental. La mise en place des Directionsdépartementales des Territoires et de la Mer (DDTM)», Revue françaised'administrationpublique, $\mathrm{n}^{\circ} 137,2011$, p. 517-535

Rouban, L. (2008), "Reform without Doctrine: Public Management in France", International Journal of Public Sector Management, "Public management reform in countries in the Napoleonic administrative tradition: France, Greece, Italy, Portugal, Spain”, 21 (2), pp. 133149 